\title{
Morphometry of the crab Hexapanopeus schmitti (Decapoda: Xanthoidea) on the northern coast of the state of São Paulo, Brazil
}

\author{
Patricia B. Fumis ${ }^{1}$, Adilson Fransozo ${ }^{1}$, Giovana Bertini ${ }^{2}$ \& Adriane A. Braga ${ }^{1}$ \\ NEBECC (Group of Studies on Crustacean Biology, Ecology and Culture) \\ 1 Departamento de Zoologia, Instituto de Biocências, Universidade Estadual Paulista. UNESP, s/n, 18618-000, \\ Botucatu, SP, Brasil; patfumis@ibb.unesp.br; fransozo@ibb.unesp.br \\ 2 Campus Experimental de Registro, Universidade Estadual Paulista, UNESP, 11900-000, Registro, SP, Brasil; giber- \\ tini@registro.unesp.br
}

Received 07-X-2005. C Corrected 17-IV-2006. $\quad$ Accepted 16-III-2007.

\begin{abstract}
A morphometric study of the xanthoid crab Hexapanopeus schmitti was carried out, using the allometric method. Samples were taken monthly for two years (1998-1999) in the Ubatuba region, northern coast of São Paulo, Brazil. Sex and size were assessed for each specimen, and all crabs were measured to obtain their carapace width (CW) and length (CL), abdomen width (AW) of females, major cheliped propodus length and height (PL and PH), and gonopod length (GL) of males. A total of 301 crabs were analyzed, 209 males and 92 females. The CWs of the crabs ranged from 2.5 to $9.8 \mathrm{~mm}$ for males and from 2.8 to $9.4 \mathrm{~mm}$ for females. The relative growth equation $\left(\mathrm{y}=\mathrm{ax}^{\mathrm{b}}\right)$ based on the relationship between GL and CW suggested that males reach their morphological sexual maturity near $6.1 \mathrm{~mm}$ CW. In females, the estimated size at $50 \%$ maturity was $4.8 \mathrm{~mm}$ $\mathrm{CW}$, based on the relationship of AW vs. CW. Males reach larger sizes than females, which probably favors their ability to guard the females during courtship. In approximately $83 \%$ of the crabs ( $n=371)$, disregarding sex, the right cheliped was larger. Rev. Biol. Trop. 55 (Suppl. 1): 163-170. Epub 2007 June, 29.
\end{abstract}

Key words: relative growth, Xanthoidea, heterochely, Hexapanopeus schmitti.

Arthropods have a growth pattern different from other zoological groups. At hatching, many of them have very different forms from those assumed by the adults; consequently, they undergo a series of transformations in the course of their development, from the post-larval to the adult phase (Mantelatto and Fransozo 1994). As growth progresses, certain dimensions of the animal's body may grow much more than others, resulting in the phenomenon known as relative growth (Hartnoll 1974).

According to Rodrigues (1985), relative growth is a morphometric relationship, described by a mathematical equation, which relates the dimensions of parts of the body or of an organ to the entire animal. Studies of relative growth are often used to determine changes in the form and size of the abdomen, pleopods or chelipeds during ontogeny.

The size at sexual maturity in crustacean populations is an important aspect of the life history of the species (Stearns and Koella 1986). Sexual maturity is understood as the set of morphological and physiological transformations whereby young or immature individuals gain the ability to produce gametes. Sexual maturity permits these animals to begin acting directly on the mechanisms of population fluctuation (Mantelatto and Fransozo 1996). The few published studies of relative growth and sexual maturity of species of Xanthoidea include those of Finney and Abele (1981), Huber (1985), Vannini and Gherardi (1988), Góes and Fransozo (1997), Guimarães and Negreiros-Fransozo (2002) and Negreiros-Fransozo and Fransozo (2003). 
The shape and size of the chelipeds are also important parameters in the life of crabs, since these structures are used for reproductive purposes and in agonistic interactions, as well as in feeding. The morphology and biomechanics of the chelae are of fundamental interest, given their importance for the ecology and evolution of the group (Bloch and Rebach 1998).

The objective of this study was to analyze the relative growth of Hexapanopeus schmitti Rathbun, 1930, based on certain morphometric relationships, and to assess the occurrence of heterochely in both sexes. Through analysis of these parameters it was possible to characterize the degree of allometry, as well as to estimate the size at which males and females reach morphological sexual maturity, thus evidencing their puberty molt.

\section{MATERIALS AND METHODS}

The crabs were collected monthly for two years (1998 and 1999), using a fishing boat equipped with double-rig tow nets, in

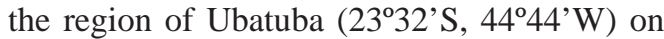
the northern coast of São Paulo state, Brazil. The individuals were identified and stored in labeled jars containing $70 \%$ ethanol. In the laboratory, the crabs were counted and sexed. Their body dimensions were measured under a stereomicroscope fitted with a drawing tube. The measurements included the width (CW) and length (CL) of the carapace, width of the abdomen of females (AW) at the base of the $5^{\text {th }}$ somite, the length and height of the propodus of the larger cheliped (PL and $\mathrm{PH}$ ), and the gonopod length of the males (GL) (Fig. 1).

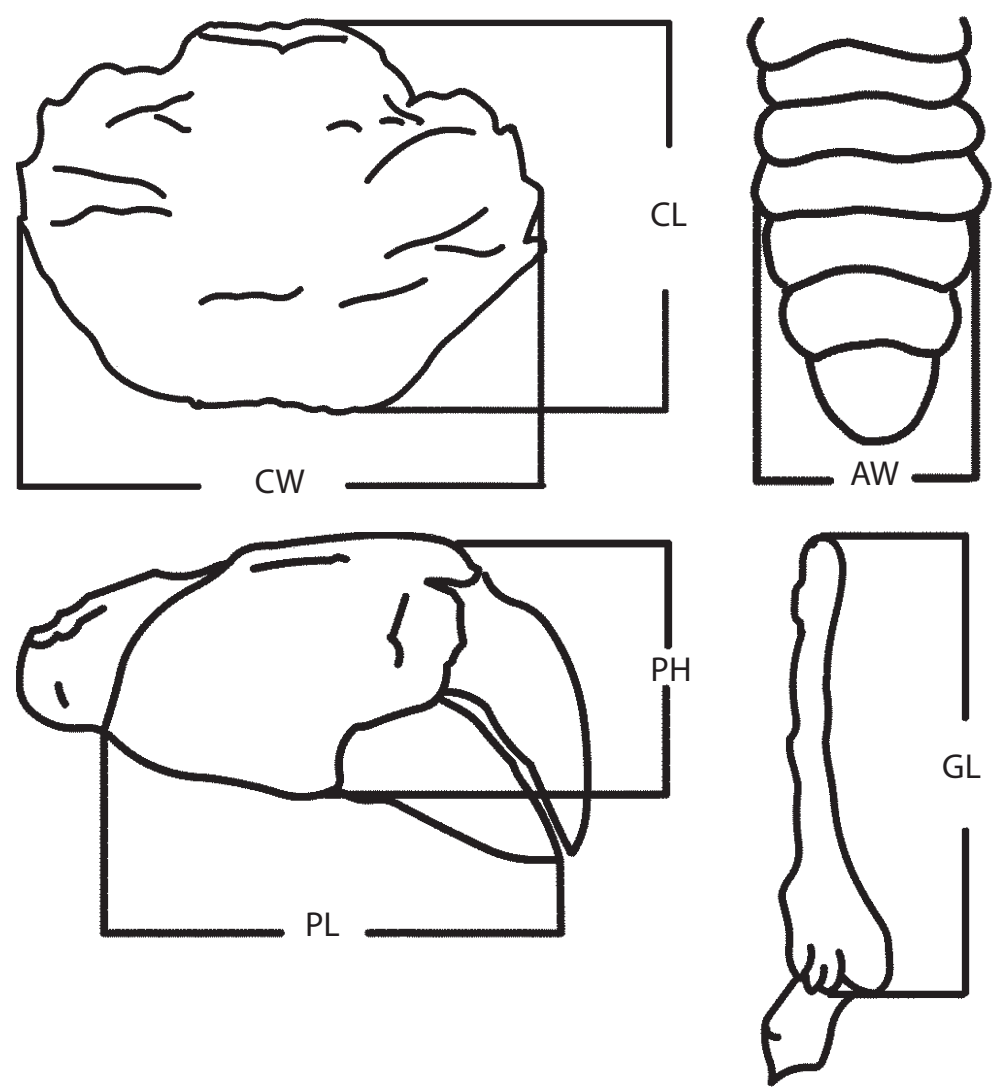

Fig. 1. Hexapanopeus schmitti. Schematic drawings of the body parts measured: $\mathrm{CW}=$ carapace width; $\mathrm{CL}=$ carapace length; AW= abdomen width; PL= cheliped propodus length; PH= cheliped propodus height; GL= gonopod length. 
TABLE 1

Hexapanopeus schmitti. Regression analyses of morphometric data

\begin{tabular}{|c|c|c|c|c|c|c|c|c|}
\hline \multirow[b]{2}{*}{ Variable } & \multirow[b]{2}{*}{ Group } & \multirow[b]{2}{*}{$\mathrm{N}$} & \multirow[b]{2}{*}{$\begin{array}{c}\text { Linearized equation } \\
\log Y=\log a+b \log x\end{array}$} & \multirow[b]{2}{*}{$r^{2}$} & \multirow[b]{2}{*}{$\begin{array}{c}\mathrm{T}^{(1)} \\
(\mathrm{b}=1)\end{array}$} & \multirow[b]{2}{*}{$\begin{array}{l}\text { Allometry } \\
\text { level }\end{array}$} & \multicolumn{2}{|c|}{ Somerton's F test } \\
\hline & & & & & & & Value $^{(2)}$ & $\begin{array}{c}\text { Cutoff } \\
\text { point }(3)\end{array}$ \\
\hline \multirow{4}{*}{ CL } & JM & 241 & $\log C L=-0.060+0.911 \log C W$ & 0.97 & $8.58^{*}$ & - & - & - \\
\hline & $\mathrm{AM}$ & 56 & $\log C L=-0.113+0.987 \log C W$ & 0.96 & $0.46^{\mathrm{ns}}$ & 0 & - & - \\
\hline & JF & 75 & $\operatorname{LogCL}=-0.059+0.903 \log C W$ & 0.94 & $3.68^{*}$ & - & - & - \\
\hline & $\mathrm{AF}$ & 47 & $\operatorname{LogCL}=-0.188+1.079 \log C W$ & 0.94 & $-2.01^{*}$ & + & - & - \\
\hline \multirow{4}{*}{ PL } & $\mathrm{JM}$ & 232 & $\log P L=-0.338+1.237 \log C W$ & 0.93 & $-10.4^{*}$ & + & - & - \\
\hline & AM & 52 & $\log \mathrm{PL}=-0.127+0.979 \log \mathrm{CW}$ & 0.77 & $0.27^{\mathrm{ns}}$ & 0 & - & - \\
\hline & JF & 65 & $\log P L=-0.217+1.009 \log C W$ & 0.93 & $-0.28^{\text {ns }}$ & 0 & - & - \\
\hline & $\mathrm{AF}$ & 43 & $\log \mathrm{PL}=-0.339+1.177 \log \mathrm{CW}$ & 0.91 & $3.03^{*}$ & + & - & - \\
\hline \multirow{3}{*}{$\mathrm{PH}$} & $\mathrm{JM}$ & 210 & $\log P H=-0.719+1.402 \log C W$ & 0.62 & $-9.06^{*}$ & + & - & - \\
\hline & $\mathrm{AM}$ & 47 & $\log \mathrm{PH}=-0.275+0.855 \log \mathrm{CW}$ & 0.83 & $1.47^{\mathrm{ns}}$ & 0 & - & - \\
\hline & $\mathrm{TF}$ & 108 & $\log \mathrm{PH}=-0.557+1.090 \log \mathrm{CW}$ & 0.90 & $-2.58^{*}$ & + & - & - \\
\hline \multirow{2}{*}{ AW } & $\mathrm{JF}$ & 31 & LogAW $=-0.793+1.488 \log C W$ & 0.78 & $-4.72^{*}$ & + & 88.3 & 4.8 \\
\hline & $\mathrm{AF}$ & 45 & $\log A W=-0.648+1.291 \log C W$ & 0.80 & $-3.01^{*}$ & + & - & - \\
\hline \multirow{2}{*}{ GL } & JM & 199 & $\operatorname{LogGL}=-0.421+0.836 \log C W$ & 0.76 & $4.94^{*}$ & - & 14.8 & 6.1 \\
\hline & $\mathrm{AM}$ & 51 & $\operatorname{LogGL}=-0.727+1.228 \log C W$ & 0.93 & $-4.75^{*}$ & + & - & - \\
\hline
\end{tabular}

$\mathrm{CL}=$ carapace length; $\mathrm{PL}=$ major cheliped propodus length; $\mathrm{PH}$ = major cheliped propodus height; $\mathrm{AW}=$ abdomen width; $\mathrm{GL}$ = gonopod length; $\mathrm{JM}$ = juvenile male; $\mathrm{AM}$ = adult male; $\mathrm{JF}$ = juvenile female; $\mathrm{AF}=$ adult female; $\mathrm{TF}=$ total female; $\mathrm{N}$ = number of specimens; 0 isometry; + positive allometry; - negative allometry.

Carapace width (CW) was used as the independent variable.

(1) Student's t-test for $\mathrm{H}_{0}$ : $\mathrm{b}=1$ : * significant at $\mathrm{p}<0.05$; ns, non-significant at $\mathrm{p}>0.05$

(2) All F-ratios correspond to $\mathrm{p}<0.05$.

(3) Size of $50 \%$ of females at maturity, estimated by Mature I analyses (AW vs. CW); estimated by maturation point (Mature II analyses) for males (GL vs. CW) (Somerton 1980a, b).

Measurements of the right and left chelipeds were used in the analysis of heterochely.

The size at sexual maturity was estimated using the programs Mature I and II (Somerton 1980a, b), according to the graphical model of the relationships.

The power function $\left(y=a x^{b}\right)$ was used for the relationship which best represents maturity for each sex. Analysis of covariance (ANCOVA) was performed to compare slopes and intercepts of the regressions obtained within each allometric relationship (Zar 1996). Departures from isometry $\left(\mathrm{H}_{\mathrm{o}}: \mathrm{b}=1\right)$ were tested using a Student's T-test on the slope values obtained ( $\alpha=5 \%)$.

The length and height of the chelar propod were log-transformed and compared between sexes by covariance analysis $(\alpha=5 \%)$ and between sides using a paired T-test (Zar 1996). The mean carapace sizes of males and females were log-transformed and compared by Student's T-test ( $\alpha=5 \%$ ).

\section{RESULTS}

A total of 451 individuals of $H$. schmitti were captured. Their sizes ranged from 2.5 to $9.8 \mathrm{~mm}$ for males $(\mathrm{n}=321)$ and 2.8 to 9.4 $\mathrm{mm}$ for females $(\mathrm{n}=130)$. The mean size of the adult males $(7.16 \pm 1.02 \mathrm{~mm})$ was statistically larger than the mean size of adult females $(5.64 \pm 0.95 \mathrm{~mm})$ (T-test, $\mathrm{p}<0.05)$.

All the equations for relative growth obtained for males and females are shown in Table 1 . The regression parameters (slope and 
intercept) of all the allometric relationships, for both sexes, were statistically different (ANCOVA, $\mathrm{p}<0.05$ ) between the juvenile and adult phases, except for the relationship PH vs. CW for females. Females showed positive allometry in the relationship AW vs. CW during both phases, indicating that the growth rate of the abdomen is higher than that of the carapace width (Fig. 2). Gonopod growth in males showed negative allometry during the juvenile phase, and positive allometry with passage to the adult phase (Fig. 3).

The morphometric relationships that best indicated the change in the allometric coefficient between juveniles and adults were gonopod length for males and abdomen width for females. Thus, according to Somerton's

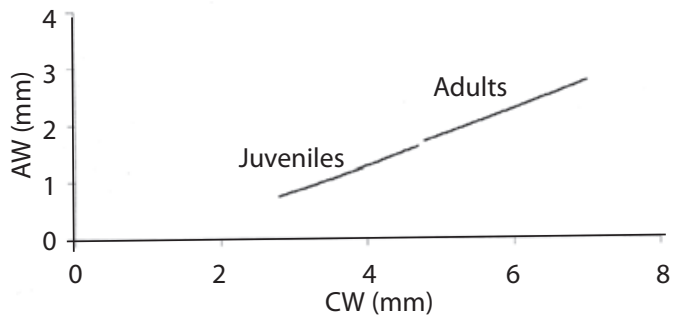

Fig. 2. Hexapanopeus schmitti. Relationship between abdomen width (AW) and carapace width (CW) in females. technique, the size at which $50 \%$ of the males reached morphological sexual maturity was 6.1 mm CW (juvenile limit $4.5 \mathrm{~mm}$ and adult limit $8.5 \mathrm{~mm}$ ), based on the GL vs. CW relationship; and for females was $4.8 \mathrm{~mm}$ CW (juvenile limit $3.5 \mathrm{~mm}$ and adult limit $5.5 \mathrm{~mm}$ ), based on the AW vs. CW relationship. These limits were estimated by inspecting the graphs.

Table 2 shows the minimum, maximum and mean sizes of the chelipeds for each sex. The mean size (length and width) of both chelipeds of males and females differed statistically, being larger in males (ANCOVA, $\mathrm{p}<0.05$ ). In both sexes, the right cheliped was statistically larger than the left one (paired T-test, $\mathrm{p}<0.05$ ) (Table 3).

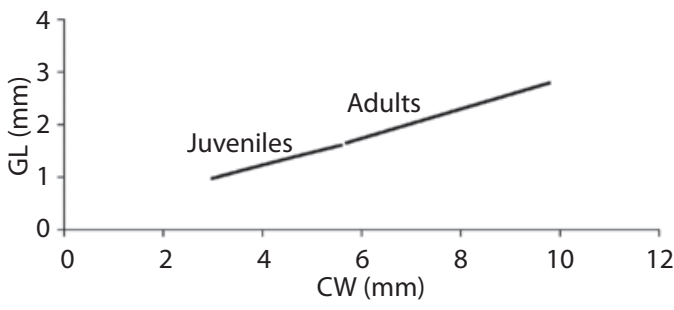

Fig. 3. Hexapanopeus schmitti. Relationship between gonopod length (GL) and carapace width (CW) in males.

TABLE 2

Hexapanopeus schmitti. Size ranges related to length and height of chelar propodus in each sex

\begin{tabular}{cccccccc}
\multirow{2}{*}{ Propodus } & Sex & \multicolumn{3}{c}{ Right } & \multicolumn{3}{c}{ Left } \\
& & Min & Max & Mean \pm SD & Min & Max & Mean \pm SD \\
Length & M & 1.5 & 7.9 & $3.43 \pm 1.1 \mathrm{aA}$ & 1.4 & 7.2 & $3.19 \pm 0.97 \mathrm{aB}$ \\
& F & 1.6 & 6.0 & $2.82 \pm 0.71 \mathrm{bA}$ & 1.5 & 5.4 & $2.61 \pm 0.63 \mathrm{bB}$ \\
\multirow{2}{*}{ Height } & M & 0.7 & 4.6 & $1.86 \pm 0.65 \mathrm{aA}$ & 0.4 & 3.7 & $1.53 \pm 0.49 \mathrm{aB}$ \\
& F & 0.8 & 3.2 & $1.45 \pm 0.39 \mathrm{bA}$ & 0.6 & 2.2 & $1.22 \pm 0.29 \mathrm{bB}$
\end{tabular}

( $\mathrm{M}=$ males, $\mathrm{F}=$ females, $\mathrm{SD}=$ standard deviation $)$.

Means followed by the same small letters do not differ statistically (within-sex comparison) (ANCOVA, p >0.05).

Means followed by the same capital letters do not differ statistically (within-side comparison) (Paired T-test, $\mathrm{p}>0.05$ ).

TABLE 3

Hexapanopeus schmitti. Predominance of the larger chela in males and females

\begin{tabular}{cccccc} 
& \multicolumn{3}{c}{ Larger chela } & Left \\
Sex & Right & N & N & $\%$ \\
Males & & 82.3 & 46 & 17.7 \\
Females & 214 & 85.6 & 16 & 14.4 \\
Total & 95 & 83.3 & 62 & 16.7
\end{tabular}

(Paired T-test, $\mathrm{p}<0.05)$. 


\section{DISCUSSION}

For brachyurans in general, when two carapace dimensions are correlated (e.g., CW and CL), changes during ontogeny do not occur, because growth tends to be isometric. This has been frequently observed; for example, for Portunus spinimanus (Santos et al. 1995), Eriphia gonagra (Góes and Fransozo 1997), Sesarma rectum (Mantelatto and Fransozo 1999) and Panopeus austrobesus (NegreirosFransozo and Fransozo 2003). However, in the case of $H$. schmitti there was differential growth between the juvenile and adult phases for both sexes, as also observed for the ocypodid Ocypode quadrata by Fransozo et al. (2002). This differential growth is probably associated with better accommodation of the gonads because of their development after sexual maturity.

The increase in abdominal width generally characterizes a distinct sexual dimorphism in representatives of the Brachyura. In the present study, from the relationship AW vs. CW it was possible to observe a change in growth of the abdomen of the females, showing a higher positive allometry in juveniles than in adults. This positive allometry may be an adaptive characteristic of the females, in which the wide abdomen provides a large area to maintain and protect the eggs, thus improving conditions for incubating the new generation (Haefner 1990, Mantelatto and Fransozo 1994). H. schmitti has a similar pattern to that found in the majority of crab species, including other species of Xanthoidea previously studied, such as Trapezia ferruginea (Finney and Abele 1981), Eriphia smithii (Vannini and Gherardi 1988), Eriphia gonagra (Góes and Fransozo 1997), Eurytium limosun (Guimarães and NegreirosFransozo 2002) and Panopeus austrobesus (Negreiros-Fransozo and Fransozo 2003).

The growth of the gonopod showed positive allometry after sexual maturity, differing from that shown by Eriphia gonagra (Góes and Fransozo 1997), but similar to that of other species such as Goniopsis cruentata (Cobo and Fransozo 1998), Panopeus austrobesus
(Negreiros-Fransozo and Fransozo 2003) and Ocypode quadrata (Fransozo et al. 2002). The relationship GL vs. CW is a useful character to estimate the beginning of sexual maturity.

Differences between the sexes in size at sexual maturity are common, and frequently encountered in brachyurans. In this study, the males of $H$. schmitti reached sexual maturity at a larger size (6.1 $\mathrm{mm} \mathrm{CW}$ ) than the females (4.8 mm CW). This has also been observed in other species (Góes and Fransozo 1997, Colpo and Negreiros-Fransozo 2003, Costa and Negreiros-Fransozo 2003, Benetti and Negreiros-Fransozo 2004). The slower growth of females in relation to males can be attributed to the former directing their potential energy principally to reproductive processes, whereas males invert more energy to somatic growth (Conan 1985, Díaz and Conde 1989).

Several researchers have noted the importance of the morphometry of chela dimensions to characterize possible sexual dimorphism and maturation in crabs (Hartnoll 1982, Abelló et al. 1990). In many brachyurans, the cheliped is larger in males than in females after sexual maturity is attained, but it is considered a secondary sex character (Hartnoll 1974).

The relationship PL vs. CW in males of $H$. schmitti showed a clear increase in the length of the propodus during the juvenile phase, with a high degree of allometry, whereas growth was less pronounced during the adult phase. In the case of females, the growth of this structure was more pronounced after morphological sexual maturation. This species shows a pattern similar to that described by Hartnoll (1982) for male brachyurans, whose growth is positively allometric during the juvenile phase and increases slightly in size after the puberty molt. However, the females showed a pattern different from that proposed by Hartnoll (1982), who affirmed the occurrence of isometry in all the phases.

The phenomenon of heterochely, which is the difference in size and function of the chelipeds, is pronounced in $H$. schmitti. In the present study, the length and height of both chelipeds differed between the sexes, 
implying sexual dimorphism, considering the size of the chelipeds. The right cheliped of this species is larger than the left one. Other studies on certain species of Xanthoidea have found similar results (Vannini and Gherardi 1988, Góes and Fransozo 1998, Guimarães and Negreiros-Fransozo 2002, Negreiros-Fransozo and Fransozo 2003).

The presence of a larger cheliped is especially important for males, because the chelae that are used in intra- or interspecific combats can achieve disproportionately large sizes (Claxton et al. 1994). Another adaptive advantage may be obtained during the breeding season, when males compete with each other for females, which are held and manipulated with the chelipeds during the entire copulatory sequence (Hartnoll 1982, Pinheiro and Fransozo 1993); or, alternately, may be related to feeding behavior (Tsuchida and Fujikura 2000). The growth patterns of the chelipeds may be related as much to reproductive behaviors as to feeding, and further studies are needed to define the true role of heterochely in this species.

\section{ACKNOWLEDGMENTS}

The authors are grateful to the Fundação de Amparo à Pesquisa do Estado de São PauloFAPESP (Grant Nos. 97/12106-8; 94/4878/8; 98/3134-6; 04/05098-0) for financial support during collections and analyses. We thank many colleagues from the NEBECC group (Group of Studies on Crustacean Biology, Ecology and Culture), who helped with sampling and laboratory analyses; to Janet Reid for her constructive comments on early drafts of the manuscript and great help with English language, and the Instituto Brasileiro do Meio Ambiente e dos Recursos Naturais Renováveis (IBAMA) for granting permission to collect the crabs.

\section{RESUMEN}

Estudiamos la alometría en el cangrejo Hexapanopeus schmitti. Los ejemplares (209 machos y 92 hembras) fueron recolectados mensualmente, durante dos años en
Ubatuba, al norte de São Paulo, Brasil. Medimos ancho (CW) y largo del caparazón (CL), ancho del abdomen (AW) de las hembras, largo y alto de los quelípedos (PL y $\mathrm{PH}$ ) y longitud del gonopodio de los machos (GL). Los CWs tuvieron un ámbito de 2.5-9.8 mm para los machos y 2.8-9.4 mm para las hembras. La ecuación de crecimiento relativo $\left(\mathrm{y}=\mathrm{ax}{ }^{\mathrm{b}}\right)$ basada en la relación GL vs. CW, sugirió que los machos alcanzan su madurez sexual morfológica aproximadamente a los $6.1 \mathrm{~mm} \mathrm{CW}$. En las hembras, la talla estimada al alcanzar un $50 \%$ de madurez fue $4.8 \mathrm{~mm}$ CW, según la relación AW vs. CW. Los machos alcanzan tallas mayores, lo cual probablemente permite una mayor habilidad para defender a la hembra durante el cortejo. La heteroquelia fue evidente (incidencia del $83 \%$ ), siendo el quelípedo derecho más grande en ambos sexos.

Palabras clave: crecimiento relativo, Xanthoidea, heteroquelia, Hexapanopeus schmitti.

\section{REFERENCES}

Abelló, P., P. Pertierra \& D.G. Reid. 1990. Sexual size dimorphism, relative growth and handedness in Liocarcinus depurator and Macropipus tuberculatus (Brachyura: Portunidae). Sci. Mar. 54: 195-202.

Benetti, A.S. \& M.L. Negreiros-Fransozo. 2004. Relative growth of Uca burgesi (Crustacea: Ocypodidae) from two mangroves in the southeastern Brazilian coast. Iheringia Ser. Zool. 94: 67-72.

Bloch, J.D. \& S. Rebach. 1998. Correlates of claw strength in the rock crab Cancer irroratus (Decapoda: Brachyura). Crustaceana 17: 468-473.

Claxton, W.T., K. Govind \& R.W. Elner. 1994. Chela function, morphometric maturity, and the mating embrace in male snow crab, Chionoecetes opilio. Can. J. Fish. Aquat. Sci. 51: 1110-1118.

Cobo, V.J. \& A. Fransozo. 1998. Relative growth of Goniopsis cruentata (Crustacea: Brachyura: Grapsidae) on the Ubatuba region, São Paulo, Brazil. Iheringia Ser. Zool. 84: 21-28.

Colpo, K.D. \& M.L. Negreiros-Fransozo. 2003. Reproductive output of Uca vocator (Herbst, 1804) (Brachyura: Ocypodidae) from three subtropical mangroves. Crustaceana 76: 1-11.

Conan, G.Y. 1985. Periodicity and phasing of molting, p. 73-100. In A.M. Wenner (ed.). Factors in adult growth. A.A. Balkema, Rotterdam, The Netherlands.

Costa, T.M. \& M.L. Negreiros-Fransozo. 2003. Population biology of Uca thayeri Rathbun, 1900 (Brachyura: Ocypodidae) in a subtropical South America 
mangrove area: results from transect and catch per unit effort techniques. Crustaceana 75: 1201-1218.

Diaz, H. \& J.E. Conde. 1989. Population dynamics and life history of the mangrove crab Aratus pisoni (Brachyura: Grapsidae) in a marine environment. Bull. Mar. Sci. 45: 148-163.

Finney, W.C. \& L.G. Abele. 1981. Allometric variation and sexual maturity in the obligate coral commensal Trapezia ferruginea Latreille (Decapoda: Xanthidae). Crustaceana 41: 113-130.

Fransozo, A., M.L. Negreiros-Fransozo \& G. Bertini. 2002. Morphometric studies of the ghost crab Ocypode quadrata (Fabricius, 1787) (Decapoda: Ocypodidae) from Ubatuba, São Paulo, Brazil, p. 189-195. In E. Escobar-Briones \& F. Álvarez (eds.). Modern Approaches to the Study of Crustacea. Kluwer/ Plenum, New York, USA.

Góes, J.M. \& A. Fransozo. 1997. Relative growth of Eriphia gonagra (Fabricius, 1781) (Crustacea: Decapoda: Xanthidae) in Ubatuba, State of São Paulo, Brazil. Nauplius 5: 85-98.

Góes, J.M \& A. Fransozo. 1998. Heterochely in Eriphia gonagra (Fabricius, 1781) (Crustacea: Decapoda: Xanthidae) of the rocky coast from Praia Grande, Ubatuba (SP), Brazil. Biotema 11: 71-80.

Guimarães, F.J. \& M.L. Negreiros-Fransozo. 2002. Sexual maturity of Eurytium limosum (Say, 1818) from a subtropical mangrove in Brazil, p 157-161. In E. Escobar-Briones \& F. Álvarez (eds.). Modern Approaches to the Study of Crustacea. Kluwer/ Plenum, New York, USA.

Haefner, P.A. 1990. Morphometry and size at maturity of Callinectes ornatus (Brachyura: Portunidae) in Bermuda. Bull. Mar. Sci. 46: 274-286.

Hartnoll, R.G. 1974. Variation in growth pattern between some secondary sexual characteres in crabs (Decapoda: Brachyura). Crustaceana 27: 131-136.

Hartnoll, R.G. 1982. Growth, p. 11-196. In D.E. Bliss (ed.). The biology of Crustacea: 2. Embryology, Morphology and Genetics. Academic, New York, USA.

Huber, M.E. 1985. Allometric growth of the carapace in Trapezia (Brachyura, Xanthidae). J. Crust. Biol. 5: 79-83.

Mantelatto, F.L.M. \& A. Fransozo. 1994. Crescimento relativo e dimorfismo sexual em Hepatus pudibundus
(Herbst, 1785) (Decapoda: Brachyura) no litoral norte paulista. Pap. Avulsos Zool. 39: 33-48.

Mantelatto, F.L.M. \& A. Fransozo. 1996. Size at maturity in Callinectes ornatus (Brachyura: Portunidae) from the Ubatuba region, SP, Brazil. Nauplius 4: 28-38.

Mantelatto, F.L.M. \& A. Fransozo. 1999. Relative growth of the crab Sesarma rectum, Randall, 1840 (Decapoda: Brachyura: Grapsidae) from Bertioga, São Paulo, Brazil. Pakistan J. Mar. Biol. 5: 11-21.

Negreiros-Fransozo, M.L. \& V. Fransozo. 2003. A morphometric study of the mud crab, Panopeus austrobesus Williams, 1983 (Decapoda: Brachyura) from a subtropical mangrove in South America. Crustaceana 76: 281-294.

Pinheiro, M.A.A. \& A. Fransozo. 1993. Relative growth of the speckled swimming crab Arenaeus cribrarius (Lamarck, 1818) (Brachyura: Portunidae), near Ubatuba, state of São Paulo, Brazil. Crustaceana 65: 377-389.

Rodrigues, S.A. 1985. Sobre o crescimento relativo de Callichirus major (Say, 1818) (Crustacea: Decapoda: Thalassinidae). Bolm. Zool. 9: 135-211.

Santos, S., M.L. Negreiros-Fransozo \& A. Fransozo. 1995. Morphometric relationships and maturation in Portunus spinimanus Latreille, 1819 (Crustacea: Brachyura: Portunidae). Rev. Bras. Biol. 55: 545-553.

Somerton, D. 1980a. Fitting a straight line to Hiatt growth diagrams: a re-evaluation. J. Conseil 39: 15-19.

Somerton, D. 1980b. A computer technique for estimating the size of sexual maturity in crabs. Can. J. Fish. Aquat. Sci. 37: 1488-1494.

Stearns, S.C. \& J.C. Koella. 1986. The evolution of phenotypic plasticity in life-history traits: predictions of reaction norms for age and size at maturity. Evolution 40: 893-913.

Tsuchida, S. \& K. Fujikura. 2000. Heterochely, relative growth, and gonopod morphology in the bythograeid crab, Austinograea williamsi (Decapoda: Brachyura). J. Crust. Biol. 20: 407-414.

Vannini, M. \& F. Gherardi. 1988. Studies on the pebble crab, Eriphia smithi MacLeay, 1838 (Xanthoidea: Menippidae): patterns of relative growth and population structure. Trop. Zool. 1: 203-216.

Zar, J.H. 1996. Biostatistical Analysis. Prentice-Hall, Upper Saddle River, New Jersey, USA, 662 p. 
